"An investigation into the levels of job satisfaction and organizational commitment amongst South African police service employees"

AUTHORS

ARTICLE INFO

DOI

RELEASED ON

JOURNAL

FOUNDER
Leigh-Anne Paul Dachapalli

Leigh-Anne Paul Dachapalli (2016). An investigation into the levels of job satisfaction and organizational commitment amongst South African police service employees. Problems and Perspectives in Management, 14(3), 76-84. doi:10.21511/ppm.14(3).2016.07

http://dx.doi.org/10.21511/ppm.14(3).2016.07

Friday, 29 July 2016

"Problems and Perspectives in Management"

LLC "Consulting Publishing Company "Business Perspectives"
NUMBER OF REFERENCES

0

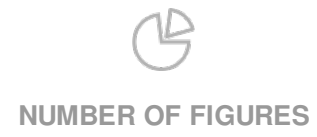

0

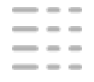

NUMBER OF TABLES

0

(C) The author(s) 2023. This publication is an open access article. 
Leigh-Anne Paul Dachapalli (South Africa)

\title{
An investigation into the levels of job satisfaction and organizational commitment amongst South African police services employees
}

\begin{abstract}
The objective of the study is to determine whether a relationship existed between the variables of job satisfaction and organizational commitment within the South African police services. Data were collected using questionnaires, administered to a sample of 103 respondents, received $71 \%$ response rate from a population of 140 employees and used the simple random sampling technique. Data were analyzed using both descriptive and inferential statistics. No statistically significant correlation was found between the dimensions of job satisfaction and organizational commitment. The ANOVA test showed a significant difference in normative commitment among the age, home language and ethnic groups. The ANOVA test revealed significant differences among the biographical variables and the job satisfaction dimensions. The findings of this study indicated no relationship between job satisfaction and organizational commitment.
\end{abstract}

Keywords: satisfaction, commitment, stressful conditions, decreased motivation, productivity, performance. JEL Classification: J28.

\section{Introduction}

South African police services seem to be faced with a number of challenges and their work has been found to be among the most stressful occupations. Long hours of work, dangerous working conditions, the high crime rate, high degrees of physical danger, violence and trauma are factors that contribute to the stressful conditions which are also related to job dissatisfaction. Police work has a number of negative consequences such as heart disease, suicide, work alienation, detachment, moodiness, depression which, as a result, decrease the commitment of police workers in the organization. Job satisfaction and organizational commitment are 2 attitude variables, in that, if individuals are satisfied on the job, this brings about commitment to the job and the organization. Elloy, Everett and Flynn (1999) indicated that "job involved individuals are more likely to be satisfied with and, thus, more committed to their jobs and organizations". Therefore, satisfaction on the job brings about commitment to the job and organization. The assumption is that job satisfaction and organizational commitment contribute either positively or negatively to productivity, performance, absenteeism and turnover. Thus, the importance of job satisfaction and organizational commitment is to make sure that the organization achieves efficiency and effectiveness.

\section{Literature review}

1.1. Job satisfaction. Moorhead and Griffin (1995) referred to job satisfaction "as an attitude that reflects the extent to which an individual is gratified by or fulfilled in his or her work". O'Reilly, Chatman \& Caldman (1991) refer to job satisfaction as an attitude that individuals maintain about their

(C) Leigh-Anne Paul Dachapalli, 2016.

Leigh-Anne Paul Dachapalli, D.Admin, Senior Lecturer, Tshwane University of Technology, South Africa. jobs and this attitude is developed from their perceptions of their job. Thus, job satisfaction has to do with individuals attitudes about their jobs.

Griffin \& Bateman (1986) maintain that, to understand job satisfaction, one needs to understand the facets of job satisfaction such as "satisfaction with work, supervision, benefits, promotion opportunities, working conditions, co-workers and organizational practices". Schmitt (2003) maintains that poor pay results in job dissatisfaction, thus, result in decreased motivation, decreased morale, poor work quality and increased turnover. Robbins (1998) further states that, for most employees, work also fills the need for social interaction. Therefore, having friendly and supportive co-workers leads to increased job satisfaction. Bennecourt and Brown (1997) suggest that employees who are given fair opportunities for promotions will be more satisfied than those who are not given these opportunities. Bassett (1994) indicates that being promoted is an almost certain source of increased satisfaction to most workers. Failing to receive a promotion can increase dissatisfaction, but only if a promotion was expected. Lincoln and Kalleberg (1990) state that the rewards offered by an organization may influence employees attitudes towards their job and the organization they work for. Dunford (1992) states that the rewards that the employee views as positive should improve job satisfaction. Recognition, another dimension of job satisfaction, is as important to success as cash or merchandise prizes offered which also increases job satisfaction (Metzler, 1998).

The consequences of job satisfaction on employees are life satisfaction, the effects of mental health and longevity, absenteeism, turnover, productivity and performance (Luthans, 1995). Many studies have shown that dissatisfied employees are more likely than satisfied employees to quit their jobs (Spector, 2000). Research indicates that when satisfaction and 
productivity data are gathered for the organization as a whole, rather than at the individual level, we find that organizations with more satisfied employees tended to be more effective than organizations with less satisfied employees (Ostroff, 1992). According to Abu-Bader (2000), a consequence of low satisfaction is low job performance. It has been established in organizational behavior literature that, although weak, job satisfaction has a positive influence on performance.

1.2. Organizational commitment. Meyer, Allen and Gellatly (1990) define organizational commitment as "the strength of an individual's identification with and involvement in a particular organization". Griffin (1996) defines organizational commitment as "an attitude that reflects an individual's identification with and attachment to the organization itself'. From the definitions above, it can be seen that organizational commitment refers to an individual's attachment, identification and involvement to the organization.

Ellermers, Gilder and Van Den Heuvel (1998) viewed organizational commitment as employee's long term involvement with and influence in an organization. "Employees who are committed to their organization are happy to be members of it, believe in and feel good about the organization and what it stands for, and intend to do what is good for the organization" (George \& Jones, 1990). According to Porter, Steers, Mowday and Boulian (1974), organizational commitment has shown to be related to: a) employee behaviors such as job search activities, turnover, absenteeism, and, to a lesser extent, performance effectiveness; b) attitudinal, affective and cognitive constructs such as job satisfaction, job involvement, and job tension; c) characteristics of the employees job and role, including autonomy and responsibility, job variety, task identity and role conflict and ambiguity, and d) personal characteristics of the employee, such as age, sex, need for achievement and job tenure.

Allen and Meyer (1990) devised a three-component conceptualization of organizational commitment, which they labeled as affective, continuance and normative commitment. Affective commitment involves the employee's emotional attachment to, identification with and involvement in the organization (Luthans, 2002). The identification, involvement and attachment of employees indicate that they are being appreciated by their organization and they, in turn, are placed in a position to assist in achieving its goals. Continuance commitment involves commitment based on the costs that the employees associate with leaving the organization. It is more about 'perceived economic advantages accrued in one's current job, relative to alternative employment opportunities' (Eisenberger, Fasolo \& Davis La-Mastro, 1990). According to the studies done by Irving, Coleman and Cooper (1997), continuance commitment often develops because of the costs associated with leaving the organization that result from investments in the organization, as well as perceived lack of alternative employment opportunities. The lack of alternatives could prevent the individual from leaving the organization.

According to Mckenna (1994), normative commitment is defined "as the obligation and responsibility felt by individuals in the organization". The employees feel it is their responsibility to help the organization to achieve its goals. According to Brunetto (2003), a study undertaken on Australian police officers suggests that police officers (being similar to other employees) will feel most committed to the organization when they are involved in decision making, feel supported by superiors and receive adequate levels of feedback about their job performance and job expectations. Employees with strong normative commitment remain members of their profession, because they feel they ought to do so (Bagraim, 2003). Research carried out on organizational commitment indicates that an employee with strong normative commitment is attracted to the organization by feelings of obligation and duty (Camilleri, 2002). It is, thus, anticipated that normative commitment will be positively related to work behavior such as job performance, work attendance, and organizational citizenship. Normative commitment might have a particularly important impact on the manner in which the work is carried out. Employees with a strong affective attachment stay with the organization, because they want to, those with a strong continuance commitment stay, because they need to and those with a strong normative commitment stay, because they feel they ought to (Allen \& Meyer, 1990; Caldwell, Chatman \& O’Reilly, 1991; Meyer, Allen \& Smith, 1993).

Organizational commitment can be categorized according to: determinants, correlates and consequences. Personal characteristics, group-leader relations, organizational characteristics, job characteristics and role characteristics have generally been considered as determinants of organizational commitment (Mowday et al., 1982). Age, gender, education, position and organizational tenure, salary and work motivation are regarded as personal characteristics that employees bring to or experience in the organization (Steers, 1997). According to Griffin \& Bateman (1986), job characteristics variables have spanned from broad 
measures of job scope, challenge or motivating potential to specific measures like task identity, feedback, responsibility and autonomy. Hackman and Oldman's (1976) job characteristics model suggests that enriched jobs are likely to yield higher organizational commitment (Steers, 1997). Current research has identified that the leadership of an organization affects organizational outcomes and influences those served by this organization (Glisson \& Durick, 1988). Group cohesiveness, leader communication, participatory leadership are factors related to group-leader relations which influences organizational commitment. Role characteristics involve role ambiguity, role conflict and role overload. Employees who report greater levels of role strain also tend to report low levels of organizational commitment (Mowday, Steers \& Porter, 1982). Affective response (that is, motivation and job satisfaction) represents a category of variables that, like commitment, describe individuals' psychological reactions to the work environment. These variables are simply considered correlates of commitment. Mowday et al. (1982) proposed that "highly committed employees are thought to be motivated to exert high levels of energy on behalf of the organization".

Withdrawal behaviors, employee performance, attendance, lateness, turnover, intention to leave, intention to search is generally considered to be consequences of organizational commitment. Camilleri (2002) states that those employees with strong affective commitment will choose to be absent less frequently and will be motivated to perform better. In a study targeted directly at job performance, it was found that affective commitment correlated positively with job performance among first level managers, while continuance commitment correlated negatively with job performance (Griffin \& Bateman, 1986). Larson \& Fukami (1984) suggest that, although high levels of commitment may relate to improved job performance in some situations, it was found that commitment has relatively little direct influence on performance, in most instances. Hanisch \& Hulin (1991) theorized that absenteeism and other withdrawal behaviors (e.g., lateness and turnover) reflect invisible attitudes such as job dissatisfaction, low level of organizational commitment or an intention to quit. The employee's level of commitment helps when determining their intentions to leave an organization. Griffin and Bateman (1986) states that turnover is the most frequently studied and reliably demonstrated consequence of low organizational commitment.

\section{Research objectives and hypotheses}

The objectives of the study were:

1. To assess job satisfaction and organizational commitment in terms of the respective dimensions and the overall scores.

2. To test whether a significant relationship existed between the dimensions of job satisfaction and organizational commitment including the overall scores.

3. To examine the influence of the biographical variables on the dimensions of job satisfaction and organizational commitment, respectively, and their overall scores.

From the objectives, three (3) hypotheses were formulated as indicated below:

Hypothesis 1: There is a significant correlation between the dimensions of job satisfaction (pay, working conditions, supervision, relation with coworkers, opportunities for advancement, equitable rewards, recognition) and the dimensions of organizational commitment (affective, normative and continuance commitment) and their overall scores.

Hypothesis 2: There is a significant difference in the perceptions of the respective dimensions of organizational commitment (affective, normative and continuance) among the respective biographical variables (age, marital status, home language, ethnic group, higher education, length of service and gender) and the overall commitment scores.

Hypothesis 3: There is a significant difference in the perceptions of the respective dimensions of job satisfaction (pay, working conditions, supervision, relation with co-workers, opportunities for advancement, equitable rewards, recognition) among the respective biographical variables (age, marital status, home language, ethnic group, higher education, length of service and gender) and the overall satisfaction scores.

\section{Research design}

3.1. Research approach. The research approach can be described as a cross sectional field survey, where data were collected at one point in time. The design is suitable to study the relationship between the different variables of job satisfaction and organizational commitment. It was a mixture of quantitative and qualitative, however, majority is quantitative. Questionnaires and interviews were used to collect primary data and data analysis used was both descriptive and inferential statistics.

\section{Research method}

4.1. Research participants. The population consisted of staff members from a police station in KwaZulu-Natal. The population comprised 140 staff 
members. The sample of 103 subjects was drawn using simple random sampling. The biographical characteristics of the study population are detailed in Table 1.

Table 1 indicates that $75.3 \%$ of the subjects were males. The highest percentage of respondents (41.1\%) fell in the age groups 31-40. According to marital status, majority of the subjects were married $(63 \%)$, whilst $49.3 \%$ of the subjects were English speaking. In the ethnic group, majority of the subjects included were Africans (47.9\%). The majority of the subjects had Matric and were below Matric (71.2\%), and $63.0 \%$ have services between 11 years and above.

Table 1. Characteristics of the sample

\begin{tabular}{|c|c|c|}
\hline & $\mathrm{N}$ & Percentage \\
\hline \multicolumn{3}{|l|}{ Gender } \\
\hline Male & 55 & $75.3 \%$ \\
\hline Female & 18 & $24.7 \%$ \\
\hline \multicolumn{3}{|l|}{ Age } \\
\hline $21-30$ & 22 & $30.1 \%$ \\
\hline $31-40$ & 30 & $41.1 \%$ \\
\hline $41-50$ & 20 & $28.8 \%$ \\
\hline \multicolumn{3}{|l|}{ Marital status } \\
\hline Married & 46 & $63.0 \%$ \\
\hline Unmarried & 27 & $37.0 \%$ \\
\hline \multicolumn{3}{|l|}{ Home language } \\
\hline English & 36 & $49.3 \%$ \\
\hline Zulu & 37 & $50.7 \%$ \\
\hline \multicolumn{3}{|l|}{ Race group } \\
\hline Blacks & 35 & $47.9 \%$ \\
\hline Whites & 38 & $52.1 \%$ \\
\hline \multicolumn{3}{|c|}{ Educational level } \\
\hline Matric \& below & 52 & $71.2 \%$ \\
\hline Post Matric & 21 & $28.8 \%$ \\
\hline \multicolumn{3}{|c|}{ Length of service } \\
\hline $10 \&$ below & 27 & $37.0 \%$ \\
\hline $11 \&$ above & 46 & $63.0 \%$ \\
\hline
\end{tabular}

Note: $\mathrm{N}=73$.

4.2. Measuring instruments. Data were collected using the shortened version of Minnesota Job Satisfaction Questionnaire developed by Weiss, Dawis, Lofquist \& England (1977) which was used to measure job satisfaction. This questionnaire comprised 21 items tapping 7 facets of job satisfaction. A five point rating scale, where (1) refers to very dissatisfied and (5) refers to very satisfied was specified by the authors. The reliability and validity of the scale was deemed acceptable by the developers.

Organizational commitment was measured by the 24 item questionnaire developed by Allen \& Meyer (1990). The questionnaire consists of three subscales, namely, affective commitment, continuous commitment and normative commitment. Subjects responded on a five point scale where $1=$ strongly disagree and $5=$ strongly agree.

In this study, unstructured interview took place after the questionnaire responses were processed. Unstructured interviews were conducted to obtain more in-depth information with regard to the subject's satisfaction and commitment levels. The interview was carried out on a few subjects.

4.3. Research procedure. Permission to conduct the study was obtained from the station commander at the police station. Each questionnaire comprised a covering letter which emphasized that participation was voluntary and confidentiality assured, a biographical section, the Job Satisfaction Questionnaire, and the Organizational Commitment Questionnaire. Questionnaires were distributed to the 103 subjects selected to participate in this study. Seventy three (73) completed questionnaires were returned which revealed a $71.8 \%$ return rate. Data were analyzed using descriptive statistics and inferential statistics.

4.4. Statistical analysis. The data from the completed questionnaires were coded as per variables and captured in SPSS (Statistical Package for Social Sciences) 11.5 version which is international standard statistical software. Data were analyzed using both descriptive and inferential statistics with SPSS 11.5.

\section{Results}

The results of the descriptive statistics are shown in Table 2 and Table 3.

Table 2. Mean, std. deviation, minimum and maximum scores for the dimensions of organizational commitment

\begin{tabular}{|l|c|c|c|c|c|}
\hline $\begin{array}{c}\text { Organizational } \\
\text { commitment } \\
\text { dimension }\end{array}$ & $\mathrm{N}$ & Minimum & Maximum & Mean & $\begin{array}{c}\text { Std. } \\
\text { deviation }\end{array}$ \\
\hline $\begin{array}{l}\text { Affective } \\
\text { commitment }\end{array}$ & 73 & 1.75 & 4.00 & 3.0634 & .44543 \\
\hline $\begin{array}{l}\text { Continuance } \\
\text { commitment }\end{array}$ & 72 & 1.25 & 4.75 & 3.3003 & .65999 \\
\hline $\begin{array}{l}\text { Normative } \\
\text { commitment }\end{array}$ & 73 & 1.63 & 4.13 & 3.1267 & .52187 \\
\hline $\begin{array}{l}\text { Overall } \\
\text { organizational } \\
\text { commitment }\end{array}$ & 72 & 1.96 & 4.00 & 3.1551 & .37381 \\
\hline
\end{tabular}

The mean scores ranged from 3.0634 to 3.3003 indicating moderate levels of commitment with normative commitment having the highest mean score.

Overall, the mean scores showed a moderate level of organizational commitment.

The standard deviation ranged from 0.44543 to 0.65999 with continuance commitment having the largest variation. 
Table 3. Mean, std. deviation, minimum and maximum scores for the sub-dimensions of job satisfaction

\begin{tabular}{|l|c|c|c|c|c|}
\hline \multicolumn{1}{|c|}{ Job satisfaction dimension } & $\mathrm{N}$ & Minimum & Maximum & Mean & Std. deviation \\
\hline Pay & 73 & 1.00 & 5.00 & 2.1781 & 1.44667 \\
\hline Working conditions & 73 & 1.20 & 2.00 & 3.4575 & .99804 \\
\hline Supervision & 73 & 1.00 & 5.00 & 2.9178 & 1.00524 \\
\hline Relation with co-workers & 73 & 2.00 & 5.00 & 3.6096 & .94372 \\
\hline Opportunities for advancement & 73 & 1.00 & 5.00 & 3.0000 & .96385 \\
\hline Equitable rewards & 73 & 1.00 & 5.00 & 3.5548 & 1.06901 \\
\hline Recognition & 73 & 1.50 & 5.00 & 3.3836 & 1.01129 \\
\hline Overall job satisfaction & 73 & 1.55 & 5.00 & 3.1573 & .78615 \\
\hline
\end{tabular}

The results show that subjects expressed satisfaction with relation with co-workers, equitable rewards. Moderate satisfaction was expressed with regard to working conditions, recognition, supervision and opportunities for advancement. Subjects recorded dissatisfaction with their pay. Overall, the mean scores showed a moderate level of satisfaction.

The standard deviation shows a variation in the perception of the job satisfaction dimension.

Hypothesis 1. There is a significant correlation between the dimensions of job satisfaction (pay, working conditions, supervision, relation with coworkers, opportunities for advancement, equitable rewards, recognition) and the dimensions of organizational commitment (affective, normative and continuance commitment).

Table 4. Pearson's correlation matrix between job satisfaction dimensions and organizational commitment

\begin{tabular}{|l|c|c|c|}
\hline \multicolumn{1}{|c|}{$\begin{array}{c}\text { Job satisfaction } \\
\text { dimensions }\end{array}$} & $\begin{array}{c}\text { Affective } \\
\text { commitment }\end{array}$ & $\begin{array}{c}\text { Continuance } \\
\text { commitment }\end{array}$ & $\begin{array}{c}\text { Normative } \\
\text { commitment }\end{array}$ \\
\hline \multirow{2}{*}{ Pay } & -.015 & -.094 & .161 \\
& .899 & .433 & .175 \\
\hline \multirow{2}{*}{ Working } & 73 & 72 & 73 \\
conditions & .033 & .065 & .119 \\
& .781 & .586 & .315 \\
Supervision & 73 & 72 & 73 \\
\hline \multirow{2}{*}{ Relation with co- } & -.054 & .154 & .225 \\
workers & .649 & .197 & .055 \\
& 73 & 72 & 73 \\
\hline \multirow{2}{*}{ Opportunities for } & .141 & .045 & -.018 \\
advancement & .093 & .706 & .880 \\
& .434 & 72 & 73 \\
\hline \multirow{2}{*}{ Equitable } & 73 & .426 & .205 \\
rewards & .069 & 72 & .082 \\
& .561 & .007 & .065 \\
\hline \multirow{2}{*}{ Recognition } & 73 & 72 & .611 \\
& .083 & .164 & .148 \\
\hline
\end{tabular}

Note: correlation is significant at the 0.01 level.

Table 4 reveals no significant correlation between the dimensions of job satisfaction (pay, working conditions, supervision, relation with co-workers, opportunities for advancement, equitable rewards and recognition) and affective and continuance commitment, respectively.

All the dimensions of job satisfaction (pay, working conditions, supervision, relation with co-workers, opportunities for advancement, equitable rewards and recognition) correlated significantly at the 0.01 level with normative commitment. Accordingly, Hypothesis 1 is only supported in the case of the job satisfaction dimensions and normative commitment.

Table 5. Overall correlations

\begin{tabular}{|l|c|c|}
\hline & Overall job satisfaction & Overall organizational commitment \\
\hline Overall job & 1 & .104 \\
satisfaction & - & .384 \\
& 73 & 72 \\
\hline Overall & .104 & 1 \\
organizational & .384 & - \\
commitment & 72 & 72 \\
\hline
\end{tabular}

The results in Table 5 indicate that there is no significant correlation between the overall job satisfaction and organizational commitment dimensions.

Hypothesis 2. There is a significant difference in the perceptions of the respective dimensions of organizational commitment (affective, normative and continuance) among the respective biographical variables (age, marital status, home language, ethnic group, higher education, length of service).

Table 6. ANOVA: biographical variables and organizational commitment dimensions

\begin{tabular}{|l|c|c|c|c|c|c|}
\hline \multirow{2}{*}{$\begin{array}{c}\text { Biographical } \\
\text { variables }\end{array}$} & \multicolumn{2}{|c|}{$\begin{array}{c}\text { Affective } \\
\text { commitment }\end{array}$} & \multicolumn{2}{c|}{$\begin{array}{c}\text { Continuance } \\
\text { commitment }\end{array}$} & \multicolumn{2}{c|}{$\begin{array}{c}\text { Normative } \\
\text { commitment }\end{array}$} \\
\cline { 2 - 7 } & $\begin{array}{c}\mathrm{F} \\
\text { value }\end{array}$ & $\begin{array}{c}\mathrm{P} \\
\text { value }\end{array}$ & $\begin{array}{c}\mathrm{F} \\
\text { value }\end{array}$ & $\begin{array}{c}\mathrm{P} \\
\text { value }\end{array}$ & $\begin{array}{c}\mathrm{F} \\
\text { value }\end{array}$ & $\begin{array}{c}\mathrm{P} \\
\text { value }\end{array}$ \\
\hline Age & .308 & .819 & .444 & .723 & 3.040 & $.035^{*}$ \\
\hline Marital status & .320 & .727 & .530 & .591 & 1.400 & .253 \\
\hline Home language & .137 & .938 & 2.312 & .084 & 6.711 & $.000^{*}$ \\
\hline Ethnic group & .883 & .454 & 2.321 & .083 & 8.798 & $.000^{*}$ \\
\hline $\begin{array}{l}\text { Highest } \\
\text { education level }\end{array}$ & 2.510 & .066 & 2.567 & .062 & .857 & .468 \\
\hline Length of service & 2.189 & .066 & .553 & .735 & .711 & .618 \\
\hline
\end{tabular}

Note: $p \leq 0.05$.

The above Anova results in Table 6 reveal a significant difference in normative commitment among the age, home language groups and ethnic 
groups. Table 6 further indicates no significant difference in the perceptions of affective and continuance commitment among the biographical variables (age, marital status, home language, ethnic group, higher education and length of service). Accordingly, Hypothesis 2 is supported only in the case of the normative commitment dimension and age, home language and ethnic groups.
Hypothesis 3. There is a significant difference in the perceptions of the respective dimensions of job satisfaction (pay, working conditions, supervision, relation with co-workers, opportunities for advancement, equitable rewards, recognition) among the respective biographical variables (age, marital status, home language, ethnic group, higher education, length of service).

Table 7. ANOVA: biographical variables and job satisfaction dimensions

\begin{tabular}{|l|c|c|c|c|c|c|c|}
\hline \multicolumn{1}{|c|}{ Biographical variables } & Pay & $\begin{array}{c}\text { Working } \\
\text { conditions }\end{array}$ & Supervision & Relation with co-workers & $\begin{array}{c}\text { Opportunities for } \\
\text { advancement }\end{array}$ & Equitable rewards & Recognition \\
\hline Age & .098 & .247 & .107 & .580 & $.021^{*}$ & .241 & .313 \\
\hline Marital status & $.050^{\star}$. & .101 & $.027^{\star}$ & .809 & .071 & .800 & .455 \\
\hline Home language & $.002^{\star}$ & $.011^{*}$ & $.000^{*}$ & $.021^{*}$ & $.000^{*}$ & .667 & $.044^{*}$ \\
\hline Ethnic group & $.007^{\star}$ & $.019^{*}$ & $.000^{*}$ & $.041^{*}$ & $.000^{*}$ & $.031^{*}$ & $.009^{*}$ \\
\hline Higher education level & .727 & .853 & .290 & .272 & .831 & .557 & .744 \\
\hline Length of service & .366 & .642 & .104 & .942 & .223 & .716 & .786 \\
\hline
\end{tabular}

Note: $p \leq 0.05$.

Table 7 indicates that significant differences were found between the following variables of job satisfaction: pay and marital status, home language and ethnic groups, working conditions and home language and ethnic groups, supervision and marital status, home language, ethnic groups, relation with co-workers and the home language and ethnic groups, opportunities for advancement and the age, home language, ethnic group and recognition and the home language and ethnic groups. Accordingly, Hypothesis 3 is supported in the following cases: pay and marital status, home language and ethnic groups; working conditions and home language and ethnic groups; supervision and marital status, home language, ethnic groups and higher education level; relation with co-workers and the home language and ethnic groups; opportunities for advancement and the age, marital status, home language, ethnic group and length of service groups; and recognition and the home language and ethnic groups.

\section{Discussion}

The objective of this study was to assess job satisfaction and organizational commitment among police personnel in terms of their respective dimensions and the overall scores; to test whether a significant relationship existed between the dimensions of job satisfaction and organizational commitment including the overall scores and to examine the influence of the biographical variables on the dimensions of job satisfaction and organizational commitment, respectively.

\section{Summary of findings}

Table 2 showed that the police personnel displayed moderate levels of commitment in terms of the overall score and the affective, continuance and normative commitment. Although the mean scores indicated moderate levels, the continuance commitment score was slightly higher that the others. This indicated that the police personnel placed slightly more emphasis on the costs associated with leaving the police force. According to Meyer et al. (1993), continuance commitment develops as an individual makes investments (e.g., the time and effort put into acquiring professionspecific knowledge and skills) that would be lost or reduced in value if he/she leaves the profession.

Table 3 revealed the levels of job satisfaction in terms of the dimensions and the overall job satisfaction score. Subjects demonstrated satisfaction with relations to co-workers and equitable rewards, moderate satisfaction with working conditions, recognition, supervision and opportunities for advancement and dissatisfaction with pay. Overall, the police personnel were moderately satisfied. Rothman and Strijdom (2002) reported that police personnel, in their study, were dissatisfied with rewards, company policies, supervision (human aspects) and physical working conditions. They experienced higher levels of job satisfaction regarding responsibility (to use their own discretion), authority (to tell others what to do) and the opportunity to work independently. Reviewing the literature on suicide ideation, Rothmans and Strijdom (2002) found that shift work, the dangers involved in police work, poor working conditions and low salaries were related to job dissatisfaction, stress and suicide tendencies. Bellingan-Timmer (2004) found that middle managers in the SAPS organized crime unit displayed significant differences in their levels of job satisfaction in terms of advancement, activity, company policies and practices, compensation, independence, moral values, social service, social status, and supervision-human relations. 
Regarding overall job satisfaction, Rothmann and Van Rensburg (2002) found that police personnel in the Marico area of the North West Province showed a practically significantly lower job satisfaction (large effect) compared to police members who are currently in training. Members in the Mooi river area of the North West Province showed a practically significantly lower job satisfaction (medium effect) compared to police members who are currently in training.

Hypothesis 1 tested whether a statistical significant relationship existed between the dimensions of job satisfaction and the dimensions of organizational commitment. Table 4 revealed no significant relationship between the job satisfaction dimensions and the organizational commitment dimensions including their overall scores. The correlation coefficients were low, in most cases, negligible. Accordingly, in this study, the results show that job satisfaction does not predict organizational commitment. Most studies reported in the literature using other population groups show a significant relationship between job satisfaction and organizational commitment.

Hypothesis 2 examined whether there is a statistically significant difference in the dimensions of organizational commitment among the biographical variables. The results shown in Table 6 revealed no significant difference in the dimensions of organizational commitment among the gender, marital status, length of service and age groups. There was a significant difference in normative commitment among the education, home language and race groups.

Police personnel who possessed a matriculation or below qualification indicated a higher level of normative commitment. In terms of the language groups, the Zulu speaking police personnel showed a stronger level of normative commitment compared to the English speaking subjects. It is possible that due to the changes that have taken place in this country, this group see the opportunities available to them and, accordingly, feel obligated to remain in the police force. Regarding the race groups, the Black police officers displayed higher levels of normative commitment compared to the other race group. Again, the same reason mentioned above could apply here.

Hypothesis 3 tested whether there was a statistical significant difference in the dimensions of job satisfaction among the biographical variables. The results in Table 7 show no significant difference in the dimensions of job satisfaction between the males and females. Significant differences were found with the following biographic variables:
- There was a significant difference in satisfaction with opportunities for advancement among the age groups. The 31-40 age group expressed stronger dissatisfaction with opportunities for advancement. People at this age group are considered to be in their mid-career stage where they go through some kind of re-evaluation of themselves when they begin to ask questions about their initial career choices, their level of achievement and their future. According to Greenhaus and Callanan (1994), mid-career is a time for looking at past gains and putting in place future goals and objectives, making amends for the past and consolidating future requirements. According to Rothmann and Strijdom (2002), unfair promotion was one of the factors responsible for job dissatisfaction, tress and suicide among police officers.

- A significant difference in satisfaction with pay, supervision and opportunities for advancement was found between married and unmarried police personnel. Married subjects displayed greater dissatisfaction with pay. Married people usually have more responsibilities and the pay they receive plays an important part. Regarding supervision and opportunities for advancement, unmarried police personnel showed greater satisfaction.

- In terms of home language, all the dimensions except equitable rewards showed significant differences. English speaking police personnel expressed a greater dissatisfaction with pay compared to the Zulu speaking group. For all the other dimensions, the Zulu speaking showed greater satisfaction than the English speaking group. This included overall satisfaction. This result is understandable in view of the changes that have taken place in this country. In the study of middle managers in the organized crime units of the SAPS, Bellingan-Timmer (2004) reported that the African language group were significantly more dissatisfied with company policies than the Afrikaans and English speaking respondents. Rothmann and Van Rensburg (2002) found no significant difference between Afrikaans and Tswana speaking police personnel in term of overall job satisfaction.

There was also a significant difference in all the dimensions of job satisfaction among the race groups except for equitable rewards. Black police personnel displayed greater satisfaction on all the dimensions compared to Whites, including overall satisfaction. Regarding pay, Whites showed a greater dissatisfaction compared to Blacks. Again, this result can be explained in terms of the changes 
in the country since independence. Rothmann \& Strijdom (2002) reported that White police personnel were relatively dissatisfied with supervision (human and technical), rewards (salaries), company policy, working condition, recognition and promotion. Black police personnel were more dissatisfied with company policies and supervision concerning total job satisfaction, Rothmann \& Strijdom (2002) found that Black respondents displayed higher levels of dissatisfaction than Whites.

There was a significant difference in satisfaction with supervision between the education groups. Subjects with a Matric and below level demonstrated a higher level of satisfaction with supervision compared to those with a post Matric qualification. With reference to length of service, there was a significant difference in satisfaction with supervision and opportunities for advancement. Police personnel with service of 10 years and below displayed greater satisfaction with supervision and opportunities for advancement compared to those with 11 years and above.

\section{Recommendations}

The results of this study revealed low levels of job satisfaction and organizational commitment except for pay where subjects were strong in their dissatisfaction. The correlation showed no significant relationship between job satisfaction. Concerning the biographical variables of home language and race groups relating to job satisfaction, the results were similar to other studies reported.

In view of the above, the results must be treated with caution. Accordingly, it is recommended that a further study be conducted with a larger sample group or the entire population. In addition, more comprehensive interviews should be conducted to clarify perceptions especially where they are low. This would either confirm or refute the results in this study.

\section{References}

1. Abu-Bader, S.H. (2000). Work satisfaction, burnout and turnover among social workers in Israel: A causal diagram, International Journal of Social Welfare, 9 (3), pp. 191-200.

2. Allen, N.J. and Meyer, J.P. (1990). The measurement and antecedents of affective, continuance and normative commitment to the organization, Journal of Occupational Psychology, 63, pp. 1-18

3. Bagraim, J.J. (2003). The dimensionality of professional commitment, Journal of Industrial Psychology, 29 (2), pp. 6-9.

4. Basset, G. (1994). The case against job satisfaction, Business Horizons, 37 (3), pp. 1-9.

5. Bellingan-Timmer, R. (2004). Job Satisfaction: An analysis of middle managers in the South African Police Service, Acta Commercii, 4, pp. 29-36.

6. Bennencourt, L.A. and Brown. S.W. (1997). Contact Employees: Relationships among workplace fairness, job satisfaction, and prosocial behaviors, Journal of Retailing, 73 (1), pp. 39-61.

7. Brunetto, Y. (2003). The Organizational commitment of early career police officers. Available at: http://www.sses.com/public/events/euram/complete_tracks/public_management/brunetto_farr-wharton.pdf.

8. Camilleri, E. (2002). Some antecedents of organizational commitment: Results from an information systems public sector organization, Bank of Valletta Review, Spring, p. 25.

9. Dunnette, M.D. (1976). Handbook of Industrial and Organizational Psychology. USA: Rand McNally College Publishing Company.

10. Eisenberger, R., Fasolo, P. and Davis LaMastro, V. (1990). Perceived organizational support and employee diligence, commitment and innovation, Journal of Applied Psychology, 75, pp. 51-59.

11. Ellmers, N., Gilder, D.D. and Van den Heuvel, H. (1998). Career Oriented and team oriented commitment and behavior at work, Journal of Applied Psychology, 83 (5), pp. 717-730.

12. Elloy, D.F., Everett, J.E. and Flynn, W.R. (1999). An examination into the correlates of Job involvement, Group and Organizational studies, 10 (2), pp. 160-177.

13. George, J.M. and Jones, G.R. (1996). Understanding and Managing Organizational Behavior. Addison-Wesley Publishing Company, Inc.

14. Glisson, C. and Durick, M. (1988). Predictors of Job satisfaction and organizational commitment in Human Science Organization, Administrative Quarterly, 33 (1), pp. 61-81.

15. Greenhaus, J.H. and Callanan, G.A. (1994). Career Management. (2nd edn). USA: The Dryden Press.

16. Griffin, R.W. (1996). Management. (5th edn). Boston: Houghton Mifflin Company.

17. Griffin, R.W. and Bateman, T.S. (1986). Job satisfaction and organizational commitment, International Review of Industrial and Organizational Psychology, 72, pp. 463-483.

18. Irving, P.G., Coleman, D.F. and Cooper, C.L. (1997). Further assessments of a three component model of occupational commitment: Generalizability and differences across occupations, Journal of Applied Psychology, 82 (3), pp. 444-452.

19. Larson, E.W. and Fukami, C.V. (1984). Commitment to company and union: Parallel Models, Journal of Applied Psychology, 69 (3), pp. 367-371.

20. Luthans, F. (1995). Organizational Behavior. (7th edn). New York: McGraw Hill, Inc. 
21. Luthans, F. (2002). Organizational Behavior. (9th edn). Boston: McGraw-Hill.

22. McKenna, E. (1994). Business Psychology and organizational Behavior. A student's handbook. USA: Lawrence Erlbaum Associates.

23. Metzler, J. (1998). The little things can help retain employees. Internet week, $743 \mathrm{p}$.

24. Meyer, J.P., Allen, N.J. \& Gellatly, I.R. (1990). Affective and continuance commitment to the organization: Evaluation of measures and analysis of concurrent and time-lagged relations, Journal of Applied Psychology, 75 (6), pp. 710-720.

25. Meyer, J.P., Allen, N.J. \& Smith, C.A. (1993). Commitment to organizations and occupations: Extension and test of a three component conceptualization, Journal of applied Psychology, 78 (4), pp. 538-551.

26. Moorhead, G. \& Griffin, R. (1995). Organizational Behavior: Managing People and Organizations. (4th edn). Boston: Houghton Mifflin Company.

27. Mowday, R.T., Porter, L.W. \& Steers, R.M. (1982). Employee-Organization linkages: The psychology of commitment, absenteeism and turnover. New York: Academic Press.

28. O'Reilly, C., Chatman, J. \& Caldwell, D.F. (1991). People and Organizational culture: a profile comparison approach to assessing person-organizational fit, Academy of Management Journal, 9, pp. 487-510.

29. Ostroff, C. (1992). The relationship between satisfaction, attitudes and performance: An organizational level analysis, Journal of Applied Psychology, pp. 963-974.

30. Porter, L.W., Steers, R.M., Mowday, R.T. \& Boulian, P.V. (1974). Organizational commitment, job satisfaction and turnover among psychiatric technicians, Journal of Applied Psychology, 59 (5), pp. 603-609.

31. Robbins, S.P. (1998). Organizational Behavior: Concepts, Controversies and Applications. (8th edn). New Jersey: Prentice Hall International, Inc.

32. Rothmann, S. \& Strijdom, G. (2002). Suicide ideation in the South African Police Services in the North West Province, Journal of Industrial Psychology, 28 (1), pp. 44-48.

33. Rothmann, S. \& Van Rensburg, P. (2002). Psychological Strengths, Coping and Suicide ideation in the South African Police Services in the North West Province, Journal of Industrial Psychology, 28 (3), pp. 39-49.

34. Schmitt, J. (2003). Pay at parity or your company will pay for it, Contractor Magazine, 50 (6), pp. 1-6.

35. Sekaran, U. (1992). Research Methods for Business. (2nd edn). New York: John Wiley.

36. Spector, P.E. (2000). Industrial and Organizational Psychology: Research and Practice. (2nd edn). New York: John Wiley.

37. Steers, E.M. (1997). Antecedents and outcomes of organizational commitment, Administrative Science Quarterly, 22 , pp. 46-56. 